Zatącznik Kulturoznawczy 3/2016

TEMAT NUMERU: KICZ NASZ WSPÓLCZESNY

\title{
O ZWIĄZKACH KICZU I PERSWAZJI
}

\section{DOROTA DĄBROWSKA}

Wydział Nauk Humanistycznych Uniwersytetu Kardynała Stefana Wyszyńskiego w Warszawie

Faculty of Humanities Cardinal Stefan Wyszyński University in Warsaw (Poland)

dkdabrowska@gmail.com

Podejmowana w niniejszym szkicu próba refleksji nad związkami kiczu i perswazji umotywowana jest poczuciem, że choć pojęcia te należą do różnych porządków (pierwsze z nich jest kategorią estetyczną, drugie natomiast wykorzystywane jest w interdyscyplinarnych analizach procesu wpływania przekazu na odbiorców), częstokroć dochodzi do ich znaczącej koegzystencji w obrębie danego dzieła. Analiza tej zależności - i konkretnych jej realizacji kulturowych - owocować może pogłębionym zrozumieniem obydwu tworzących ją zjawisk.

Interesująca mnie relacja ma dwa oblicza: jedno naznaczone oczywistością, drugie niejasnością. Pierwsze $\mathrm{z}$ nich wiąże się z obecnością perswazji w kiczu (włącznie z możliwością uznania jej za jego podstawowy budulec), drugie natomiast $-\mathrm{z}$ generowaniem kiczu przez przekazy o charakterze perswazyjnym. Zacznę od tego pierwszego.

Wydaje się, że niezależnie od sposobu, w jaki rozumiemy perswazję, jest ona nieodzownym składnikiem kiczu. Jego sposób istnienia i cel związane są bowiem z dążeniem do jednoznaczności, uwiedzeniem prowadzącym ku określonym przeżyciom. Kicz pozbawia swojego odbiorcę indywidualności, a jego działanie jest wymierzone na osiągnięcie określonego efektu. Wpisana weń unifikacja jest nie tylko efektem ubocznym uwodzenia, ale wręcz jego oczekiwanym rezultatem - doświadczenie wspólnotowości przynosi ukojenie, pogłębia stan wzruszenia, poczucie swojskości.

Kicz wyciska dwie łzy wzruszenia. Pierwsza łza mówi: jakie to piękne, dzieci biegnące po trawniku! Druga łza mówi: jakie to piękne, wzruszać się wraz z całą ludzkością dziećmi biegnącymi po trawniku! Dopiero ta druga łza 
robi z kiczu kicz. Braterstwo wszystkich ludzi świata można zbudować wyłącznie na kiczu' ${ }^{1}$.

Upodobnienie odbiorców, uczynienie z nich jednolitej masy, stanowi podstawę „przeżycia kiczowego" ${ }^{2}$. Wpisane w nie doświadczenie ulgi i ukojenia wynika z braku jednostkowej odpowiedzialności, z poczucia bezpieczeństwa - przypominającego to, którego doświadcza dziecko będące pod opieką troskliwych rodziców:

W krainie kiczu panuje dyktatura serca. Ale uczucie, które budzi kicz, musi być takie, aby mogły je podzielać masy. Dlatego kicz nie może się opierać na sytuacji wyjątkowej, lecz na podstawowych obrazach, które ludzie mają wbite w świadomość: niewdzięczna córka, odtrącony ojciec, dzieci biegnące po trawniku, zdradzona ojczyzna, wspomnienie pierwszej miłości³

Andrzej Banach, przeciwstawiając przeżycie estetyczne - kiczowemu, konkluduje:

Ostatnią cechą kiczowego przeżycia estetycznego jest jego zespołowość. W czystym przeżyciu estetycznym człowiek pragnie być sam. Nawet szept mu przeszkadza. W przeżyciu kiczowym, gdzie ciało ma dużą rolę, człowiek staje się częścią całości, elementem zbioru ${ }^{4}$.

Kicz wiąże się zazwyczaj z intencją wyrazistego, jasnego przekazu ${ }^{5}$, nie pozostawia miejsca na namysł. Ma na celu uporządkować świat, pozbawić odbiorcę niepokojów, poruszyć go. Inaczej jednak niż we wstrząsającym, „burzącym” doświadczeniu katharsis - ma pogłębić lub przywrócić stan komfortu mocą rozładowującego napięcie rozwiązania. Są w niego wpisane „Zrozumiałość i przejrzystość rozumiane jako imperatyw bezpośredniego,

1 M. Kundera, Nieznośna lekkość bytu, tłum. A. Holland, Warszawa 1996, s. 189.

2 A. Banach, O kiczu, Kraków 1986, s. 52.

3 M. Kundera, op. cit., s. 188-189.

4 A. Banach, op. cit., s. 64.

5 Zob. T.P. Wójcik, Familiarność disco polo i brutalność heavy metalu. Zmierzch kultury czy nowa jej forma u progu XXI wieku, [w:] Kicz, tandeta, jarmarczność w kulturze masowej XX wieku, red. L. Rożek, Częstochowa 2000, s. 111. 
niczym niezakłóconego i natychmiastowego dotarcia do odbiorcy"6. Abraham Moles określa kicz mianem „totalitaryzmu bez przemocy”, Andrzej Banach mówi, że jest to „przedmiot, nawet przeciwnik, bardzo niebezpieczny”, nazywa go „dziełem zakłamania”, wskazując, że „u podstaw jego budowy znajduje się wola zaprowadzenia poczciwego odbiorcy tam, gdzie się podoba artyście"8. Może się to dziać w sposób mniej lub bardziej wyraźny. Banach, rozwijając wątek wpisanego w kicz niebezpieczeństwa, zauważa:

Jeżeli bowiem kicz wydaje nam się niebezpieczny, to właśnie dlatego, że ktoś ukryty poza artystą, a choćby i sam artysta, daje nam sygnał, a my, nieświadomi, ulegamy mu. Mechanizm kiczu to wywołanie odruchów jakby wrodzonych, dziedzicznie utrwalonych?

Kicz zamienia się zatem w tajemnicze narzędzie kontroli, uniemożliwia swobodną, wolną interpretację wykreowanej rzeczywistości przez odbiorcę. Banach zwraca również uwagę na automatyzację procesu działania kiczu ${ }^{10}$.

W rozważaniach nad interesującą mnie kategorią zwraca się często uwagę, że choć zasadniczo jest w nią wpisana taniość, warsztatowa mierność, to niekiedy - a nawet przeważnie - mamy do czynienia z wariantem kiczu jakościowo zgoła odmiennym. Rozpatrując etymologię słowa 'kicz' pod kątem jej związków z wyrazem 'szkic', Banach konkluduje:

Niestety podobieństwo między szkicem a kiczem wyczerpuje się w sferze brzmienia. Poza tym wszystko je dzieli. Kicz dzisiejszy [...] jest często znakomicie wykończony, drogi, wspaniały, podobający się publiczności ${ }^{11}$.

Jedno z podstawowych kryteriów kiczu okazuje się zatem posiadać status alternatywny, opcjonalny, niekonieczny. Choć bylejakość, prowizoryczność i imitacyjność zdają się stanowić podstawowe jego cechy, ostatecznie ich brak

${ }^{6}$ K. Citko, Kino komercyjne jako domena kiczu - tradycja i współczesność, [w:] Kicz, tandeta, jarmarczność..., op. cit., s. 117.

7 A. Moles, Kicz, czyli sztuka szczęścia: studium o psychologii kiczu, tłum. A. Szczepańska, E. Wende, Warszawa 1978, s. 219.

8 A. Banach, op. cit., s. 33.

9 Ibidem, s. 147.

10 Ibidem, s. 151.

11 Ibidem, s. 10. 
nie odbiera obiektowi/utworowi „kiczowej” tożsamości. Jako przykład dzieła, które dobrze reprezentuje opisaną powyżej jakość, potraktować można film Młodość Paolo Sorrentino, przeanalizowany przez Marię Beszterdę pod kątem niebezpiecznej bliskości patosu i wzniosłości oraz kiczu ${ }^{12}$. Choć formalne wyrafinowanie i oryginalność stanowią przeciwieństwo niedbałości i bylejakości cechujących masowe produkcje, nie gwarantują jednak automatycznie statusu dzieła sztuki. Katarzyna Citko za jedną z istotnych cech kiczu uznaje „nagromadzenie efektów i ornamentów pozbawionych funkcji”"13. Naddatek w zakresie estetycznej złożoności dzieła grozi pretensjonalnością ${ }^{14}$ - uwaga ta wskazuje na konieczność wyjścia w analizie i interpretacji kiczu poza kryteria estetyczne ku refleksji nad funkcją użytych środków.

Obserwacja wskazująca na alternatywność kryteriów orzekania o kiczu skłania do namysłu nad tym, w jakim stopniu poszczególne cechy mu przypisywane muszą być reprezentowane w danym obiekcie, by móc adekwatnie określić jego tożsamość jako „kiczową” właśnie.

Inspirujące dla refleksji nad związkami kiczu i perswazji są prace wykraczające poza sferę estetyczną, ujmujące kicz w kategoriach etycznych. We wstępie do Refleksów nazizmu Saula Friedländera Paweł Śpiewak stwierdza radykalnie:

Kicz [...] bywa określany jako zła sztuka, bezguście, zdegenerowane piękno, a powinno się go nazwać po prostu kłamstwem. Jeśli tak uczynimy, zapewne nazwiemy go również złem, a wtedy okaże się, że to, co uchodziło za kwestię smaku, estetyki, stosunku do piękna, nabiera charakteru etycznego. Te dwa podejścia, estetyczne i etyczne, mieszają się w licznych rozprawach o kiczu i okazują się nierozdzielne ${ }^{15}$.

${ }_{12}$ M. Beszterda, Sorbet $z$ Sorrentino, http://e.czaskultury.pl/czytanka/film/1984sorbet-Z-sorrentino [data dostępu: 31.07.16].

13 K. Citko, op. cit., s. 117.

14 „Pretensjonalność jako uroszczenie, domaganie się więcej, niż się należy, przybieranie lepszych pozorów, obliczanie na wyrost, udawanie większego, doskonalszego. Wszystkie te cechy znajdziemy w stanie doskonałym w kiczu jako jego składnik konieczny". A. Banach, op. cit., s. 78.

15 P. Śpiewak, Wstęp, [w:] S. Friedländer, Refleksy nazizmu: esej o kiczu iśmierci, tłum. M. Szuster, Warszawa 2011, s. 10-11. 
Powyższe rozważania nie sprowadzają się do stwierdzenia, że to, co estetycznie mało wartościowe, jest niegodne ludzkiego poznania, lub też że niewinna - jak się pozornie wydaje - „szmira” może być szkodliwa. Kierują również ku namysłowi nad szczególnym potencjałem owej „złej sztuki” prowadzącym do kształtowania masowych wyobrażeń. Przykład kiczu nazistowskiego bardzo klarownie ujawnia ciężar tego oddziaływania.

Drugie oblicze relacji między kiczem a perswazją, które określiłam jako naznaczone niejasnością, ujawnia się w pytaniu o możliwość „stwarzania” kiczu przez perswazję, a zatem uobecniania się tej kategorii - o statusie stricte estetycznym - niejako niezależnie od estetycznej tożsamości dzieła. Wyrażona powyżej konstatacja, że nie sposób traktować względów czysto formalnych jako wyznaczników kiczowatości dzieła (skoro kicz - jak postaram się dalej wskazać - pojawić się może w także w realizacjach wyrafinowanych i oryginalnych), skłania ku twierdzeniu, że w próbie identyfikacji utworu pod kątem uobecniania się w nim interesującej nas kategorii zmuszeni jesteśmy analizować i interpretować tworzące go elementy w kontekście jego całości, rozpoznawać ową „taniość” na różnych płaszczyznach. Można sądzić, że istnieje szczególnego rodzaju więź między kiczem i tymi tekstami kultury, które pozbawiają odbiorcę podmiotowości, a zatem uznają go za ściśle zaprogramowanego na określone przeżycia i wnioski. Ze względu na tę „taniość”, konwencjonalność - zmierzającą nie całkiem jawnie ku zjednaniu sobie odbiorcy - intuicyjnie odbieramy jako kiczowate utwory propagandowe i tendencyjne.

Perswazja stanowi pojęcie bardziej ogólne, wskazujące na wszelkiego rodzaju próby nakłaniania do przyjęcia określonego sposobu rozumienia rzeczywistości. W przeciwieństwie do dzieł o charakterze propagandowym, w utworach, które skłonni bylibyśmy traktować jako perswazyjne (skłaniając się ku użyciu kategorii bardziej ogólnej, mniej ostrej), możemy mieć do czynienia z subtelnością, wieloznacznością, artystycznym wyrafinowaniem ${ }^{16}$. Równocześnie jednak teksty kultury o charakterze perswazyjnym - niezależnie od swojej formalnej złożoności - są zazwyczaj skoncentrowane na idei ściśle określonego wpływu na odbiorcę, która podporządkowuje sobie wszystkie elementy dzieła, zamieniając je w artefakt o statusie bliskim

${ }_{16}$ Zob. K. Sasaki, Głębsza retoryka. Mechanizm propagandy jako perswazji, „Estetyka i Krytyka” 2003, nr 1(4), s. 4-5. 
politycznemu manifestowi. Przekaz taki pozbawiony jest zwykle bezpośredniości, wpisane w perswazję „przekonywanie” dokonuje się nie całkiem otwarcie ${ }^{17}$. Oczywiście, ze względu na ogólność znaczenia tego pojęcia napotkamy również zjawiska, które choć określane są jako perswazyjne, to nie odznaczają się zasygnalizowanymi powyżej cechami. W niniejszych rozważaniach ograniczam się do jednego $\mathrm{z}$ wielu sposobów rozumienia perswazji, wskazującego na jej podobieństwo do propagandy ${ }^{18}$.

Przykładem tekstu kultury, w którym interesujące nas kategorie - kicz i perswazja - ściśle się ze sobą łączą, jest popkulturowy film Bóg nie umarł (2014) w reżyserii Harolda Cronka. Można by mówić w tym wypadku wręcz o propagandowym charakterze dzieła, co nie zmienia jednak zasygnalizowanego tu kierunku analizy (jako że propagandę traktuję jako jedną z odmian perswazji). Film opowiada o młodym studencie amerykańskiej uczelni, uczestniku kursu filozofii. Prowadzący zajęcia nauczyciel jako punkt wyjścia, niejako warunek dopuszczenia do udziału w konwersatorium, traktuje stwierdzenie „Bóg umarł”, pod którym ma się „podpisać” każdy z uczestników. Główny bohater filmu, Josh, ze względu na osobiste przekonania nie jest gotów spełnić tego oczekiwania, w związku z czym zostaje przed nim postawione wyzwanie - warunek zaliczenia kursu stanowi przekonanie reszty studentów do fałszywości twierdzenia propagowanego przez wykładowcę. Fabuła filmu skoncentrowana jest na zmaganiach Josha - wewnętrznej walce o wierność wyznawanym wartościom oraz próbom sprostania intelektualnemu wyzwaniu. Jak można się spodziewać od pierwszych minut filmu,

17 Zob. S. Barańczak, Czytelnik ubezwłasnowolniony: perswazja $w$ masowej kulturze literackiej PRL, Paryż 1983, s. 30: „Obserwatora kultury masowej zainteresować jednak musi pewien specyficzny rodzaj funkcji konatywnej: uzewnętrznia się on nie tyle we wszystkich możliwych funkcjach czynników wypowiedzi, których zadaniem jest odwołanie się do odbiorcy, ile raczej w tych szczególnych czynnikach, które determinują lub usiłują zdeterminować zachowanie (mentalne lub fizyczne) odbiorcy. I to zdeterminować w sposób pośredni, niejako utajony, nie zaś drogą bezpośrednich zakazów czy nakazów. Taką właśnie szczególną odmianę funkcji konatywnej proponowałbym nazwać funkcją perswa zyjną".

18 Zob. R. Garpiel, Przegląd koncepcji perswazji, [w:] idem, Perswazja w przekazach kaznodziejskich na przykładzie homilii Jana Pawła II wygłoszonych podczas pielgrzymki do Polski w roku 1979, Kraków 2003, s. 37-41. 
starania te przynoszą oczekiwany rezultat - zapalczywy nauczyciel ponosi porażkę, a odważny uczeń triumfuje.

Film Bóg nie umarł opisywany jest przez dystrybutora jako „pasjonujący spór filozoficzny w opowieści o poszukiwaniu odpowiedzi na najważniejsze pytanie w dziejach ludzkości”. To wzniosłe, pozytywnie wartościujące sformułowanie budzi pewne zastrzeżenia. Rzeczywistość przedstawiona w filmie od samego początku ujawnia wyraziste nacechowanie aksjologiczne - wszyscy bohaterowie żyjący w oderwaniu od religii chrześcijańskiej borykają się z problemami, cechuje ich egoizm, brak wrażliwości na innych. Mamy zatem do czynienia $z$ wyrazistą opozycją - świat ludzi wierzących w Chrystusa oraz świat tych, którzy go odrzucają. Ilustrują to poboczne wątki filmu - między innymi historia pracoholiczki skoncentrowanej na „miażdżeniu” swoich oponentów dziennikarskimi paszkwilami, jej bezdusznego partnera, który na wiadomość o jej chorobie postanawia się z nią rozstać, brutalnego muzułmanina wymuszającego na swojej córce noszenie chusty i stosowanie się do restrykcyjnego prawa uniemożliwiającego jej normalne funkcjonowanie w społeczeństwie. Wszyscy ci bohaterowie w sposób wręcz karykaturalny skonstruowani są w oparciu o pewne schematy. Przykład stanowić może scena, w której dziennikarka-pracoholiczka w odpowiedzi na wiadomość o chorobie mówi „Nie mam czasu na raka, jestem zbyt zajęta”, lub też moment, w którym jej partner na sugestię, by odwiedził swoją matkę, odpowiada: „Przecież kupiłem jej telewizor”. Karykaturalny charakter tych stereotypowych obrazów nie wydaje się jednak zabiegiem intencjonalnym, nie przekracza bowiem granicy, poza którą ukazane sytuacje prowokowałyby do śmiechu. Mamy zatem raczej do czynienia z próbą bardzo dosadnego odzwierciedlenia trudności doświadczanych przez ludzi żyjących w oddaleniu od świata wartości moralnych i religijnych.

Czarno-biały charakter wykreowanego w filmie świata najpełniej ujawnia się w zestawieniu dwóch głównych bohaterów: gotowego do poświęceń, wiernego samemu sobie studenta i cynicznego, narzucającego swoje przekonania innym wykładowcy. Profesor Radisson jest postacią negatywną - cechuje go brak szacunku dla wolności innych, złośliwość (określa wiarę jako „prymitywne przesądy”), jak również skłonność do zastraszania i nieuczciwego traktowania uczniów. Od pierwszego spotkania bohaterów widoczne jest, że siły są nierówne. Widz nie ma możliwości sympatyzowania z wykładowcą i tym samym traktowania poważnie jego racji. Gdy więc dochodzi do 
uzyskania przewagi przez studenta i profesor zostaje zmuszony do przyznania, że w istocie wierzy on w istnienie Boga, ale Go nienawidzi (ze względu na doświadczenie osobistego dramatu w dzieciństwie), odbiorca przyjmuje to rozwiązanie bez zaskoczenia. Scena zwycięstwa studenta jest - ujmując rzecz wprost - kiczowata: zarówno ze względu na użyte w niej środki estetyczne (wyciskająca łzy muzyka, patetyczna i konwencjonalna gra aktorska), jak i na swoją oczywistość i wynikającą z tego zestawienia pretensjonalność.

Postać Josha - reprezentującego najsilniej propagowane w utworze wartości - zostaje uwznioślona. Jego działania opierają się na wyrażonym przez niego przekonaniu, że tylko prawdziwe zagrożenie jest sprawdzianem wiary. Podjęcie decyzji o walce o prawo do własnych przekonań zyskuje w filmie aurę radykalnego i kosztownego kroku. W konsekwencji bohater zostaje porzucony przez dziewczynę, grozi mu utrata społecznego uznania oraz „samobójstwo akademickie”. Wszystkie te zagrożenia są jednak niczym wobec przekonania, że działania Josha są wyrazem pragnień Boga.

Twórcy filmu Bóg nie umarł mieli ambicje ukazania prześladowań, jakich doświadczają chrześcijanie: studenci nie mają prawa swobodnego wyrażania wiary, dziewczyna wychowywana w ortodoksyjnej rodzinie muzułmańskiej zostaje brutalnie wyrzucona $\mathrm{z}$ domu, gdy wychodzi na jaw, że praktykuje chrześcijaństwo. Problematyka ta zostaje jednak ujęta w sposób, który lekceważy wpisany w nią ciężar. Banalizacja dokonuje się poprzez konwencjonalizację oraz posłużenie się środkami estetycznymi właściwymi przekazom popkulturowym (szczególnie wyraźnie widać to w scenie wyrzucania dziewczyny z muzułmańskiego domu, której towarzyszy popowa piosenka z wyeksponowaną w refrenie frazą „Carry on!”). Interesująca z punktu widzenia refleksji nad warsztatową „taniością” filmu byłaby również analiza sceny poprzedzającej „nakrycie” modlącej się chrześcijanki przez jej muzułmańskiego braciszka: kamera śledząca subtelne ruchy bohaterów, ujęcie drzwi i przekręcającej się gałki, kontrasty wywołujące wyraźne napięcie - wszystko to stanowi konwencjonalne elementy filmów grozy. Zapożyczenie to wywołuje - przez swojego rodzaju pretensjonalność i niespójność z tematyką filmu - efekt komiczny, który wydaje się nie tyle celowym zabiegiem reżyserskim, ile niefortunnym skutkiem ubocznym.

Film jest równocześnie kiczowaty w warstwie warsztatowej (dialogi rażące sztucznością, nieumiejętna gra aktorska, budząca wątpliwości sprawność reżyserska) i perswazyjny w sposób ocierający się o propagandę (co zostaje 
szczególnie dobitnie podkreślone przez drobny zabieg zacierający granicę między fikcją a rzeczywistością - wieńczący film napis „Dołącz do nas i wyślij wiadomość do znajomych”). Wydaje się jednak, że ujawnia się w nim coś więcej niż tylko doskonała koegzystencja tych dwóch jakości. Kiczowatość utworu osiąga swoje ekstremum właśnie z ścisłym spleceniu z zabiegami zastosowanymi w celu „przechwycenia” odbiorcy, zjednania go dla jedynej słusznej, niedyskusyjnej interpretacji świata, jaką przynosi - zbanalizowane skądinąd - chrześcijaństwo. Film nie ma charakteru wypowiedzi stricte ewangelizacyjnej, ale poprzez wykreowanie sugestywnego wizerunku wyznawców pewnej religii - chrześcijan - dąży do ujednoznacznienia obrazu świata, pozostawienia odbiorcy bez pytań i wątpliwości.

Podobnie wnioski można wysnuć na podstawie analizy utworu radykalnie odmiennego estetycznie od Bóg nie umarł, a mianowicie powstałego w 2015 roku filmu Małgorzaty Szumowskiej Body/Ciało. W dziele tym niezwykle wyraźnie ujawnia się interesujące mnie zjawisko. W pierwszym odruchu, na podstawie pobieżnego oglądu, trudno uznać ostatni film Szumowskiej za utwór kiczowaty. Body/Ciało nie jest z pewnością filmem warsztatowo miernym - nie miejsce tu na dogłębną analizę poszczególnych jego warstw, intuicyjny ogląd, podparty głosami krytyków, pozwala jednak uznać, że mamy do czynienia $z$ utworem wyrafinowanym i sprawnie skonstruowanym. Wrażenie charakterystycznej dla kiczu „taniości” ujawnia dopiero sugestywna „wymowa” filmu i - jak wskazują możliwe do prześledzenia świadectwa jego odbioru - nie ma charakteru uniwersalnego. Żeby przyjrzeć się znaczeniu końcowej sceny, warto zrekonstruować pokrótce fabułę i dokonać jej interpretacji.

Body/Ciało opowiada o „osieroconej” rodzinie - Januszu i jego córce, Oldze, bolejących po śmierci bliskiej im osoby - żony i matki. Doświadczenie to staje się źródłem poważnych problemów tożsamościowych bohaterów. Choć nie wiemy do końca, czy jest ono przyczyną alkoholowych trudności i stanu zblazowania, w jakim znajduje się ojciec, oraz bulimicznych i samobójczych tendencji jego córki, obserwujemy ich nasilenie w tym właśnie kontekście. Ponadto oboje pozostają niepogodzeni ze śmiercią i utratą bliskiej osoby. W przypadku dziewczyny wyraża się to tęsknotą (o której opowiada w czasie rozmowy z terapeutką), w przypadku jej ojca - niepokojami związanymi z lękiem przed ingerencją zmarłej w jego świat codzienny. Janusz pełen napięcia obserwuje łopoczącą firankę, z przestrachem wyłącza radio, które się nagle 
„samo włączyło”, z namysłem i obawą reaguje na uwagi sąsiada dotyczące głośnej muzyki, rzekomo słuchanej przez któregoś z domowników. Odbiorca filmu nie widzi w tym niepokoju niczego absurdalnego, szereg drobnych przypadków komponuje się spójnie i przekonująco w obraz stanu uzasadnionej obawy. Kontrapunkt dla zbudowanego przez Janusza światopoglądu - racjonalistycznego, bliskiego postawie cyniczno-sardonicznej - stanowi zatem osobiście doświadczany lęk, będący z jednej strony reakcją emocjonalną, z drugiej zaś wyrazem wątpliwości ujawniających się na poziomie intelektualnym. Bohater w swojej codziennej egzystencji „twardo stąpa po ziemi”, jest niewzruszony, z ostentacyjną beznamiętnością przyjmuje wiadomości o najgorszych zbrodniach, a nawet obserwuje ich ślady. Śmierć żony zmienia ten stan rzeczy - w jego świat zaczyna się wkradać niepewność w kwestii istnienia życia pozaziemskiego. Temat ten wypada uznać za kluczowy dla Body/Ciało, organizujący jego sensy, wchłaniający pośrednio wszystkie obecne w nim wątki. Postacią reprezentującą świat duchowy, odrzucaną przez bohatera wiarę w możliwość obcowania ze zmarłymi oraz w życie po śmierci, jest Anna, terapeutka Olgi oraz - jak się z czasem dowiadujemy - medium spirytystyczne. Janusz początkowo reaguje na bohaterkę z niechęcią, odnosi się bez szacunku do jej sugestii dotyczących sposobu opieki nad córką, a przede wszystkim możliwości skontaktowania się ze zmarłą. Z czasem, wraz z narastaniem poczucia niepokoju, jego podejście zaczyna się zmieniać - rozmyśla o kwestiach metafizycznych, podejmuje je w dyskusjach z przyjaciółką, inicjuje rozmowę $\mathrm{z}$ terapeutką, a ostatecznie zgadza się na udział w seansie spirytystycznym mającym doprowadzić do spotkania ze zmarłą żoną.

Scena seansu spirytystycznego jest kluczowa dla rozwijanego w filmie dialogu między sceptycyzmem wobec metafizyki a wiarą w jej istnienie. Od rezultatów owego eksperymentu - jak wciąż postrzega go mimo wszystko Janusz - zależy bowiem nie tylko jego stosunek do wspomnianej kwestii, ale równocześnie pewnego rodzaju diagnoza zawarta w filmie - mamy bowiem do czynienia z prowadzeniem widza przez zawiłości analizowanej kwestii, tworzeniem pozoru dialogu rywalizujących ze sobą racji. Gdy zatem seans spirytystyczny okazuje się porażką - nie pojawiają się żadne oznaki obecności zmarłej, a medium zasypia i chrapie (co komicznie pogłębia swego rodzaju dewaluację reprezentowanego przez Annę świata) - dokonuje się także oczyszczenie horyzontu emocjonalnego i aksjologicznego filmu. Ostatnia jego scena pokazuje rozpromieniające się twarze dwójki bohaterów, którzy - pod wpływem zaśnięcia Anny - uwalniają 
się od niepokojów i tęsknoty, a w ich oczach pierwszy raz widzimy wolność i szczęście. Towarzyszą temu określone środki estetyczne - rozbrzmiewa radosna, rockowa muzyka, pokój zalewa ciepłe, poranne światło. Ujawniająca się w tej scenie zmiana jest wyraźna i daje poczucie ukojenia, rozwiązania, zamknięcia. Ze względu na konwencjonalność zastosowanych chwytów sygnalizujących rozwianie niepokojów, które dręczyły bohaterów, scenę tę można określić jako kiczowatą lub co najmniej kiczem naznaczoną. Kicz pojawia się w niej - i tu dochodzę do kwestii kluczowej - nie tylko jako konwencjonalna estetyka, ale też rezultat wpisanej w film perswazji. Wrażenie taniości, pewnego rodzaju nieuczciwości, odczucie, że widz został potraktowany nie całkiem poważnie, wynika z otrzymania jednoznacznej, gotowej odpowiedzi na pytania wpisane w doświadczenie obcowania ze skomplikowanym, złożonym problemem. Rozmaite artystycznie złożone konceptualizacje zagadnienia cielesności i duchowości okazują się zmierzać jedynie do dewaluującej ich złożoność konkluzji, która nie pozostawia miejsca na żadne wątpliwości. Można by oczywiście zadać pytanie o sens ostatniego ujęcia filmu - stołu, przy którym odbywał się seans spirytystyczny, widzianego z zewnątrz. Nie ma już przy nim śpiącej bohaterki. Zasnęła i spadła pod stół? Została przeniesiona na łóżko? Wcale nie istniała? A może, paradoksalnie w stosunku do wymowy filmu, zniknęła - jak znikają duchy - potwierdzając własne racje? To drobne ujęcie pozwala widzieć w strukturze filmu element otwartości. Wydaje się jednak, że ciężar kiczowatego rozwiązania akcji nie zostaje poprzez ten subtelny drobiazg przełamany i to on pozostaje „ostatnim słowem” utworu.

Teza wskazująca na możliwość identyfikowania jako kiczowatych zjawisk odmiennych estetycznie od „kiczowego kanonu”, a zatem niereprezentujących całego wachlarza jakości łączonych z tą kategorią, pozwala pogłębić refleksję nad jej złożonością i sytuacjami, kiedy wykracza poza sferę czysto estetyczną. Zasygnalizowane w tym szkicu kierunki interpretacji wybranych tekstów kultury potraktować można jako próbę wykorzystania w praktyce badawczej teorii uwzględniających dwie płaszczyzny oddziaływania kiczu, jego szczególną, dwoistą naturę.

\section{Bibliografia:}

Andrzej Banach, O kiczu, Wydawnictwo Literackie, Kraków 1968.

Stanisław Barańczak, Czytelnik ubezwłasnowolniony: perswazja w masowej kulturze literackiej PRL, Libella, Paryż 1983. 
Marta Beszterda, Sorbet $z$ Sorrentino, http://e.czaskultury.pl/czytanka/ film/1984-sorbet-z-sorrentino.

Katarzyna Citko, Kino komercyjne jako domena kiczu - tradycja i współczesność, [w:] Kicz, tandeta, jarmarczność w kulturze masowej XX wieku, red. L. Rożek, Wydawnictwo WSP, Częstochowa 2000.

Rafał Garpiel, Przeglad koncepcji perswazji, [w:] idem, Perswazja w przekazach kaznodziejskich na przykładzie homilii Jana Pawła II wygłoszonych podczas pielgrzymki do Polski w roku 1979, Nomos, Kraków 2003.

Milan Kundera, Nieznośna lekkość bytu, tłum. A. Holland, PIW, Warszawa 1996. Ken-ichi Sasaki, Głębsza retoryka. Mechanizm propagandy jako perswazji, tłum. M. Bokiniec, „Estetyka i Krytyka” 2003, nr 1(4).

Paweł Śpiewak, Wstęp, [w:] Saul Friedländer, Refleksy nazizmu: esej o kiczu i śmierci, tłum. M. Szuster, Wydawnictwa UW, Warszawa 2011.

Tomasz Paweł Wójcik, Familiarność disco polo i brutalność heavy metalu. Zmierzch kultury czy nowa jej forma u progu XXI wieku, [w:] Kicz, tandeta, jarmarczność w kulturze masowej XX wieku, red. L. Rożek, Wydawnictwo WSP, Częstochowa 2000.

\section{Filmografia:}

Body/Ciało (2015), reż. Małgorzata Szumowska.

Bóg nie umarł (2014), reż. Harold Cronk.

\section{Relations Between Kitsch and Persuasion}

The article concerns the problems of the relationship between kitsch and persuasion; it is an attempt to approach this relationship from two perspectives - indicating the persuasive nature of kitsch as one of its characteristics, and signaling the possibility of recognizing that kitsch category is present as a consequence of giving the communique a persuasive character. The presented statements have been based on the analysis of two films - God is not dead, directed by Harold Cronk, and Body/Ciało, directed by Małgorzata Szumowska.

Keywords: persuasion, kitsch, manipulation, Harold Cronk, Małgorzata Szumowska 